during many discussions. The pertinent technicality is that the information in a patent application must not be made public before the application is filed. At the conference worries emerged about universities with secret enclaves protecting trade secrets, but there were several other indications of the turmoil which the explosion of the field has caused. Doubtless there will be ill effects in some places, real or perceived, but it is hard to believe that all this striving will not in the end produce many benefits. Even so care must be taken that commercial interests do not distort the values of an academic laboratory.

Patenting of Life Forms is not the simplest way for molecular and cell biologists to learn about patenting or for patent agents to learn about the science. Nonetheless it does give all the basic information, and in the discussions exposes many misconceptions and starts to unravel a number of them. The book may in the end be of most interest to historians as an example of the evolving attitudes of scientists in the field.

Norman Carey is Director of Research at Celltech, Slough, Berkshire.

\section{Beginning on bacilli}

\section{Julius Marmur}

\section{Bacillus subtilis. The Molecular \\ Biology of the Bacilli, Vol.1. \\ Edited by David A. Dubnau.}

Academic: 1982. \$44, £29.20.

IS A WHOLE volume on Bacillus subtilis and its phages justified? The short answer is "yes". David Dubnau, the editor, has selected some fine reviewers who handle the genetics, biochemistry, physiology and industrial aspects of the "second major prokaryotic subject for the study of molecular biology" with expertise at a level that will satisfy biologists ranging from graduate students to members of faculty. He has obviously done much to prevent serious overlap and has taken great pains to cross-reference information.

In the beginning, and always, there is E.coli. But, in relation to E.coli, B.subtilis has some different features and advantages - it is gram-positive, sporulates, is much more competent in DNA-mediated transformation and is sensitive to a wider variety of antibiotics; catabolite repression in $B$. subtilis does not involve cAMP, and the organism possesses an elaboratc system for extracellular excretion and yields protoplasts that can fuse and revert efficiently; operons, if they exist, are rare; finally, $B$. subtilis is more readily handled for industrial exploitation than $E$. coli.

Most of the authors have covered their fields broadly, discussing information more fully than is usual in an Annual
Review article, presenting an historical perspective and, inevitably, emphasizing the comparative biology and biochemistry with that of $E$. coli. Comparisons have also been made to $S$. pneumoniae (transformation) and to other Bacillus species. Since most of the authors have spent a good deal of time working in the areas they cover, their own studies are discussed in considerable detail (in a few cases, perhaps too much) and references are up to date.

Dubnau's own contribution, "Genetic Transformation in Bacillus subtilis", is one of the highlights of the book. His hope "that the reader will be left with a clearer understanding of the molecular mechanisms involved in the uptake, processing and integration of transforming DNA" is fulfilled admirably. Plausible models and critical evaluations of results are helpful and useful. Dubnau explains why plasmid monomers fail to transform competent $B$. subtilis cells (making it difficult to shotgun clone homologous DNA into this organism). His discussions also have a direct bearing on other chapters.

Losick's chapter, "Sporulation Genes and their Regulation", is one of the most personalized and speculative presentations in the text. He proposes a positive transcriptional control model involving modifications of RNA polymerase promoter recognition components and interaction with spore gene encoded proteins to explain the developmental progression of "a developmentally ordered program of gene activation" in sporulation.

Examining this book, one wonders whether the information and concepts generated by work on $B$. subtilis will have a wider influence (as $E$. coli did) in the study of gene expression (which is the major emphasis in the book) in other organisms. The studies will certainly continue to affect research on other Bacillus species. An area where such influence might prove to have wider significance is based on the exciting investigations on developmental programming during spore development and temporal virulent phage DNA expression. In both cases changes in transcriptional patterns appear to be related to changes in RPase promoter recognition proteins and, in the case of sporulation, would also appear to involve the interaction of several gene products. Probably the most important role that the bacilli will play will result from their exploitation in the fermentation industry. The manipulation and improvement of strains need no longer be limited to a few traditional approaches.

This first volume to The Molecular Biology of the Bacilli is a very good beginning to the series. One looks forward with anticipation to subsequent volumes that will cover areas such as morphology, repair, chemotaxis, enzyme excretion and the molecular biology of other species.

Julius Marmur is Professor of Biochemistry and Genetics at the Albert Einstein College of Medicine, New York

\section{Through the British Quaternary}

\section{Björn Kurtén}

\section{Pleistocene Vertebrates in the British}

Isles.

By A.J. Stuart.

Longman: 1982. Pp.212. £16.50, \$38.

THE study of Pleistocene vertebrates in Britain is beset with problems. Most of the fossil material (and much of the best) was collected long ago, with insufficient regard to stratigraphy - sometimes an entire cave was emptied in a few days. Furthermore, the collections are scattered in numerous local museums, and are in various states of curation. Working on such material, the student often finds himself with minimal returns as regards problems of fine stratigraphy, evolution at the population level and the like.

The haze is now being dispelled by a younger generation of palaeontologists. Many recent studies focus on the small mammals, of which stratigraphically localized and statistically respectable samples can be obtained relatively easily, using modern collecting techniques. Of special importance has been the great advance of Pleistocene palaeobotany in the British Isles, and vertebrate palaeontology at its best is now developed hand in glove with palaeobotany. The author of the present volume is one of the leading students in this area and his handsome book is a fine testimony to all of the work carried out in recent decades.

Although palaeobotany is an excellent climatic tool, the slow evolution of plant species makes it somewhat insensitive for biostratigraphical analysis (the same holds for palaeoentomology); by contrast, the rapidly evolving mammalian species may help to discern cases of repeated, essentially similar climatic cycles. The number of interglacials in the later Pleistocene, for instance, is disputed. Palaeobotanists distinguish three (the Hoxnian, Ipswichian and Flandrian), while comparison with the climatic record obtained from marine sediments suggests a greater number. This is currently the main controversy, and the author adheres to the threeinterglacial scheme, although properly noting that it may become a strait jacket.

\section{Cheaper fluid dynamics}

Springer-Verlag have issued a paperback "study edition" of Joseph Pedlosky's Geophysical Fluid Dynamics. The new edition is a corrected reprint of the original hardcover edition of 1979. and costs DM63, \$26.30. Hydrodynamic Stability by P.G. Drazin and W.H. Reid (reviewed in Nature 294, 196; 1981) has also recently appeared in paper covers. Publisher is Cambridge University Press, price $£ 12.50$, $\$ 24.95$ 